
ТАКСОНОМІЯ ДИДАКТИЧНИХ УМОВ РЕАЛІЗАЦІї ДІЯЛЬНІСНОГО ПІДХОДУ
У ПРОЦЕСІ ПІДГОТОВКИ ВЧИТЕЛЯ ІНОЗЕМНОЇ МОВИ

\title{
TAXONOMY OF DIDACTIC CONDITIONS FOR THE IMPLEMENTATION OF THE ACTIVITY APPROACH IN THE PROCESS OF TRAINING A FOREIGN LANGUAGE TEACHER
}

Стаття присвячена актуальній проблемі, важливість якої пояснюється тим, що однією із ключових компетентностей, котрі повинні фрормуватися у майбутніх фрахівців, $\epsilon$ знання іноземної мови. Саме тому постає проблема забезпечення високого рівня підготовки вчителів іноземних мов, яку неможливо розв'язати без кардинальних змін у методологічній та практичній площинах організації і здійснення цього процесу на відповідному дидактико-методичному рівні. Одним з ефективних способів, що сприяють вирішенню означеної проблеми, $є$ реалізація діяльнісного підходу.

мета статті полягає в обгрунтуванні розробленої моделі фрункційно-структурної дидактичної системи реалізації діяльнісного підходу в процесі підготовки вчителя іноземних мов та таксономії організаційно-дидактичних умов їі срункціонування.

В ході дослідження застосовувалися теоретичні, емпіричні та статистичні методи. Функційно-структурна дидактична система представлена чотирма компонентними конструктами: концептуально-дидактичний, змістово-дієвий, фрункційно-дієвий, рефрлексійно-діяльнісний. Кожен із названих конструктів включає в себе субконструкти, а саме: концептуально-дидактичний: методологічний, теоретичний, технологічний, психолого-дидактичний: змістово-дієвий: організаційно-дієвий, когнітивно-змістовий; функційно-дієвий: субконструкт мотивації діяльності майбутнього вчителя та інструментально-діяльнісний субконструкт; ресрлексійно-діяльнісний: діагностувальноінструментальний, компетентнісно-верифрікаційний та аналітико-статистичний субконструкти.

Фундаційною основою ефективного функціонування окресленої функційно-структурної дидактичної системи є виявлені дидактичні умови та їх класифікація.

Наукова новизна дослідження полягає в обгрунтуванні моделі ффункційно-структурної дидактичної системи, яку утворюють чотири компонентних конструкти. Означена модель фрункціонує на основі виявленої таксономії організаційно-дидактичних умов. У статmі зазначається, що динамічні зміни рівнів профресійної підготовки майбутніх учителів іноземної мови засвідчують позитивне значення розробленої моделі окресленої вище фрункційно-структурної дидактичноі системи та створеної таксономії організаційно-дидактичних умов реалізації діяльнісного підходу.

Перспективи подальших досліджень вбачаються у розробці нових концепцій реалізаціі діяльнісного підходу.

Ключові слова: переосмислення, інтеграція, система цінностей, освітній процес, науково-педагогічні ідеї.

The article is devoted to a topical issue, the importance of which is explained by the fact that one of the key competencies that should be formed in future professionals is knowledge of a foreign language, as the main feature of modern business and everyday life is multilingualism. That is why, the article notes there is a problem of ensuring a high level of training of foreign language teachers, which cannot be solved without radical changes in the methodological and practical are as of organization and implementation of this process at the appropriate didactic and methodological level.

The purpose of the article is to substantiate the created taxonomy of organizational and didactic conditions for the implementation of the activity approach in the process of training a foreign language teacher.

The study used theoretical, empirical and statistical methods.

A prominent place in the article is outlined by the functional-structural didactic system of implementation of the activity approach and the created taxonomy of organizational-didactic conditions of effective functioning of the specified system.

Functional structural didactic system is represented by four component constructs: conceptual-didactic, content-effective, functionaleffective, reflection-activity. Each of these constructs includes subconstructs, namely: conceptual-didactic: methodological, theoretical, psychological, technological didactic; semanticeffective: organizational-effective, cognitivesemantic; functional-effective: subconstruct of motivation of the future teacher and instrumentalactivity subconstruct; reflection-activity: diagnostic-instrumental, competence-verification and analytical-statistical subconstructs.

In this article, there is a manifestation and creation of a taxonomy of organizational and didactic conditions (at three levels), namely: 1) paradigmatic-system-forming organizationaldidactic condition; 2) as et of subcontracting organizational and didactic conditions; 3) partial sub-conditions (elements of conditions) with in each of the subcontracting conditions.

The scientific novelty of the study is that for the first time the didactic bases of the activity approach in the process of foreign language teacher training were determined, which are presented as a theoretical substantiation of the developed model of the functional-structural didactic system in the unity of interconnected component constructs and creation of the taxonomy of organizational-didactic conditions (at three levels).

The article notes that the dynamic changes in the levels of professional training of future foreign language teachers, testify to the positive importance of the developed model of the above functional-structural didactic system and the created taxonomy of organizational-didactic conditions for the implementation of the activity approach.

Key words: rethinking, integration, value system, educational process, scientific and pedagogical ideas. 
Постановка проблеми. В умовах константного реформування системи освіти загалом та вищої освіти зокрема проблема підготовки педагогічних кадрів вимагає наукового переосмислення системи цінностей, формування професійно значущих якостей, актуалізує пошук оптимальних форм і методів навчання.

Інноваційні процеси в навчанні передбачають фрормування у майбутніх фрахівців здатності навчатися упродовж життя. Одним з ефективних способів, що сприяє розв'язанню цієї проблеми, ми вважаємо реалізацію діяльнісного підходу у його новому баченні. У фрормуванні компетентності «навчатися упродовж життя» важлива роль належить знанням іноземної мови. Володіння іноземною мовою забезпечує якнайширший доступ особистості до різноманітних джерел інфрормації. Саме тому вивчення потенційних можливостей застосування діяльнісного підходу у процесі підготовки вчителів іноземних мов $€$ досить актуальним.

Аналіз наукових досліджень. Історико-дидактичний пошук показує, що теоретичному обґрунтуванню проблеми діяльнісного підходу присвячено наукові дослідження вчених, котрі здійснювалися в різних аспектах, зокрема фрілософському, психологічному, педагогічному.

Діяльнісний підхід як наукова категорія бере свої витоки у психології С. Рубінштейна, О. Леонтьєва. [3, с. 120]. Аналізуючи працю Платона «Менон», С. Рубінштейн наголошував свого часу на думках грецького фрілософра Платона (427-347 рр. до н. е.), у яких визначено сутність діяльнісного підходу до навчання, а саме: «знання не повідомляються в готовому вигляді за принципом переливання з однієї посудини в іншу; знання не можна пізнати, якщо під навчанням розуміти просту передачу, механічну рецепцію в готовому вигляді поданої мудрості; навчатися - означає оволодівати своїми власними пізнаннями» [7, с. 101].

Діяльнісний підхід як психолого-педагогічне явище набув розвитку в працях сучасних українських (Г. Атанов, І. Бех, Л. Зайцева, Н. Гузій, Г. Іванюк, В. Лозова, Т. Севустьяненко, Б. Сусь, М. Шут) і зарубіжних (О. Бондаревська, І. Зимня, Т. Стефановська, В. Сєріков, С. Якиманська та інші) вчених.

На нашу думку, досить влучно тлумачить сутність діяльнісного підходу до навчання І. Зимня. «Засвоєння знань, - вважає вона, - відбувається одночасно з засвоєнням дій» [2, с. 24-26].

Своєрідне бачення сутності діяльнісного підходу пропонує Г. Атанов. На його думку, діяльнісний підхід - це навчання діяльності. Під діяльністю розуміється саме навчальна діяльність, яка охоплює всі відомі в педагогіці способи організації навчального процесу [1, с. 160].

Сутність діяльнісного підходу та його місце у дидактиці розглядають Б. Сусь та М. Шут [8, с. 5-8].
На важливості визнання діяльнісного підходу основною парадигмою теорії навчання наголошує А. Реан. Науковець вважає, що цей підхід «орієнтує не на зміст готових структур свідомості, а на процес, у результаті якого вони виникають, і, як наслідок, приводить до глибшого розуміння їх природи» [6, с. 175].

Розглядаючи навчання 3 позицій діяльнісного підходу, Г. Щукіна вважає, що без навчальної діяльності не може розвиватися особистість [10, с. 15-16]. «Особистість є суб'єктом діяльності і спілкування з іншими людьми», - вважає О. Малихін [4, с. 29-44].

Попри чималі здобутки в теорії діяльності, розроблення концептуальних ідей цього підходу дотепер перебуває на стадії становлення загальних уявлень, а в педагогічній теорії і практиці проявляється фррагментарно.

Аналіз наукових досліджень показує, що професійній підготовці фахівців приділяється велика увага. Однак теоретичні основи профресійної підготовки вчителя іноземної мови на основі реалізації діяльнісного підходу обґрунтовано недостатньо. Відсутня структура системи досліджень професійної підготовки фрахівців цієї галузі.

У контексті здійснюваного дослідження у площині дидактики вищої школи важливо з'ясувати сутність змісту категорії «діяльнісний підхід» в історико-дидактичному розвитку й особливості його впровадження в освітній процес вищої школи в оновленому парадигмальному сприйнятті загалом, а також в освітній процес вищої педагогічної школи в умовах її кардинальної реформації в контексті реалізації положень Концепції «Нова українська школа» (2016) зокрема. Саме тому здійснюємо спробу логічно та послідовно проаналізувати означене поняття на сутнісно-деоініційному рівні та в історико-дидактичному вимірі. Адже тільки проникнення в його сутнісне розуміння уможливлює осмислення й усвідомлення всіх багатовимірних виявів діяльнісного підходу, як уже було зазначено, із позицій його традиційно-класичного сприйняття, а також 3 позицій його оновленого парадигмального виміру як діє-орієнтованого [9, с. 47].

Новизна нашого дослідження полягає в тому, що була розроблена модель фрункційно-структурної дидактичної системи і створена таксономія організаційно-дидактичних умов реалізації діяльнісного підходу в процесі підготовки вчителя іноземної мови. Отже, метою статті є обґрунтування створеної таксономії організаційно-дидактичних умов реалізації діяльнісного підходу в процесі підготовки вчителя іноземної мови.

Виклад основного матеріалу. Виявлення та обґрунтування дидактичних умов реалізації діяльнісного підходу в процесі підготовки вчителя іноземної мови представляє великий інтерес, 
оскільки ефрективність цього процесу великою мірою залежить від їх реалізації. Поняття «умова» має неоднозначне визначення. Ми зупиняємось на позиціях, котрі було визначено на узагальненому рівні за результатами теоретичного аналізу проблеми та які $€$ особливо актуальними для дослідження реалізації діяльнісного підходу в професійній підготовці майбутнього вчителя іноземної мови, а саме:

- умови розглядаються з точки зору цілісності та взаємодії складників (стійкий рухомий зв'язок) як доцільний варіант об'єднання (комплекс, система), поділ на які може бути об'єктивно детермінованим чи суб'єктивно заданим (спеціально створеним);

- як обставини, що визначаються опосередкованістю активності особистості у педагогічному процесі, структурною організацією комплексу та його безпосередньою підпорядкованістю цілям розвитку дидактичної системи, у її контексті - підсистем (супідрядних систем).

У своєму дослідженні ми спиралися на визначені певні положення таксономічного підходу. Таксономія (від грец. - «класифікація» і «наука») може розглядатися як певна фрундаційна платформа щодо систематизації, упорядкування та надання класифікації нелінійних, комплікативних (іноді навіть контраверсійних) багаторівневих складноструктурованих систем, котрі не $є$ адитивним поєднанням компонентів, які входять до їх складу. Саме тому звертаємось до певної таксономії в упорядкуванні дидактичних впливів, котрі в узагальненому вигляді в межах здійснюваного дослідження представлено як організаційно-дидактичні умови, що створюються циклічно та ієрархічно-рівнево, залежно від умови найвищого ієрархічного рівня, яка може уявлятися і конкретизуватися як створення комплексу умов нижчого ієрархічного рівня й розкладатися на часткові умови до нескінченності. В цьому і вбачається доцільність вивчення їхньої взаємодоповнюваності, взаємовпливовості, взаємопроникнення та взаємореконструювання в разі виникнення непередбачуваних ситуаційно зумовлених внутрішніх і зовнішніх чинників, котрі можуть бути як позитивно інфрлуенційними, так і певним чином деструктивними.

Вияв, фрормулювання та створення будь-яких умов спирається також на реалізацію положень ресурсного підходу, що передбачає винайдення, з одного боку, зовнішніх ресурсів освітнього середовища, що втілюється в ретельному аналізі дидактичного потенціалу актуального у певний історичний час освітнього процесу (його організації та здійснення), освітніх (педагогічних чи власне дидактичних) технологій, фрорм організації, методів, прийомів і засобів навчання, котрі застосовуються в межах певних дидактичних систем, і більш конкретних методик навчання за урахування зако- номірностей і принципів на різних рівнях, таких як: мотиваційно-ціннісний, організаційно-змістовий, процесуально-діяльнісний, результативний, контрольно-оцінювальний, рефлексійний, а 3 іншого боку, винайдення внутрішнього ресурсу суб'єктів навчання.

Організаційно-дидактичні умови в межах здійснюваного дослідження трактуємо з огляду на наведені вище концептуальні положення і розуміємо як різновид дидактичних умов, де визначально-фрункційним $€$ забезпечення організаційного складника, ураховуючи специфіку досліджуваного дидактичного феномена, котрий визначається ключовим концептом «реалізація діяльнісного підходу».

Виходячи із трактування сутності поняття «організаційно-дидактичні умови», обґрунтованого О. Малихіним на комплікаційно-комбінаторній основі, ми визначили таксономію організаційнодидактичних умов реалізації діяльнісного підходу в процесі підготовки вчителя іноземної мови, під якими розуміємо визначену комплексну сукупність потенційно містких дидактичних ресурсів і вихідних положень, створення і реалізація яких сприятиме вдосконаленню процесу навчання 3 урахуванням постійно змінюваних вимог до якості отриманих знань, умінь та навичок, що у своїй структурно-фрункціональній єдності забезпечують фрормування необхідних компетенцій і компетентностей [5, с. 11-14].

Пристосовуючи трактування сутності поняття «дидактичні умови» до предмета здійснюваного дослідження, акцентуємо увагу на деяких актуальних особливостях, а саме: асоціювання поняття «умова» з потенційно місткими ресурсами є досить нетиповим і таким, що вказує на умову з позиції можливості резервів (подекуди прихованих) оптимізації діяльності, застосування яких потребує їх розуміння, технологічних особливостей актуалізації. Поняття «резерви» $є$ достатньо високоохоплювальним і таким, що вбирає всі зазначені вище ідентифрікатори поняття різних дослідників (обставини, чинники, характеристики, параметри, фрорми, методи та інші). Наголос на потенційній місткості ресурсів свідчить про те, що вони не $є$ певною особливістю, яку об'єктивно закладено в процес, і здійснюють свій вплив не на ефективність його протікання, а на потребу їх педагогічно грамотної активації, актуалізації. Комплексна сукупність як системотвірна характеристика умов свідчить про необхідність пошуку варіанту оптимального їх поєднання, взаємодоповнення, найвищого рівня інтеграції, що забезпечує цілеспрямований, прогнозований системний вплив. Засадничою методологічною позицією, об'єднувальною платфрормою слугуватимуть висхідні положення, на ґрунті яких вони визначаються, отримують адекватне змістове наповнення та комплексуються 
в інтегративні утворення. На методологічні основи компетентнісної основи вказує результуючий складник створення та фрункціонування дидактичних умов, що об'єднуються як отримані знання, уміння і навички, формування яких неодмінно програмується у своїй структурно-фрункціональній єдності (яка не є фріксованою, незмінною), що виступає іманентною ознакою профресійної компетентності фрахівця.

Формуючи таксономію організаційно-дидактичних умов реалізації діяльнісного підходу у підготовці вчителя іноземної мови, враховували проблеми та недоліки, котрі супроводжують виявлення та визначення дидактичних умов забезпечення ефрективності освітніх процесів, навчальної діяльності, що було здійснено на основі аналізу наукових джерел з означеної теми.

Дискретний підхід до визначення дидактичних умов, за яким вони представляються як досить автономні позиції, що не відображають закономірних зв'язків і взаємообумовленостей між сутнісними змістово-процесуальними складниками, а також між самими умовами, нівелюючи ефекти «накладання» та конфлліктності (взаємовиключення).

Формування комплексу умов, які належать до різних кваліфікаційних груп, тобто вони не мають спільних концептуальних засад і в їх основі передбачається актуалізація різних механізмів і процесів.

Недостатній рівень теоретичної обґрунтованості проблеми виділення групи умов, що сприяють оптимізації навчальних, педагогічних процесів, у тому числі їх специорікації відповідно до заданої проблематики, а також алгоритмів їх дотримання, орієнтуючись на цілісність інтегрально-фрункціональної моделі розвитку.

Важливо підкреслити, що під час виявлення, конкретизації та фрормулювання таксономії досліджуваних організаційно-дидактичних умов ми враховували: сучасні методологічні підходи до підготовки майбутнього вчителя, особливостей компетентнісної, особисто зорієнтованої системи профресійного навчання, потенційні можливості особистісного, професійного розвитку та саморозвитку студента з тенденцією до збільшення питомої ваги самоуправління в його структурі.

Реалізація положень таксономічного підходу до дослідження організаційно-дидактичних умов реалізації діяльнісного підходу в процесі підготовки вчителя іноземної мови зумовлена тим, що компетентнісна модель освітньої діяльності визначає необхідність системно-комплікативного трактування освітніх явищ, процесів, що допомагають зрозуміти їх сутнісну природу в комплексі зв'язків і залежностей, які визначають спосіб і механізми їх функціонування та розвитку

Отже, дидактичні умови визначаються, структуруються, класиорікуються на основі системот- вірних цілей моделі, концептуальних засад її реалізації, що отримали відповідне теоретичне обґрунтування, а також визначених у моделі фрункційних блок-конструктів системи (психодидактичної пропедевтики; мотивації вияву соціальної суб'єктності в освітньому процесі; інтеріоризації змісту профресійно-фрілологічної значущої підготовки; активації соціокогнітивних процесів в інтегрованій освітній діяльності); виявлення критеріїв та опис рівнів вияву функційного результату як сорормованості професійної компетентності вчителя іноземної мови.

Організаційно-дидактичні умови реалізації діяльнісного підходу в процесі профресійної підготовки вчителя іноземної мови представляємо на трьох ієрархізовано-підпорядкованих рівнях :

- парадигмально-системотвірна організаційно-дидактична умова реалізації діяльнісного підходу в процесі підготовки вчителя іноземної мови;

- комплекс організаційно-дидактичних субумов;

- елементно-часткові умови.

Парадигмально-системотвірна організаційнодидактична умова реалізації діяльнісного підходу в процесі підготовки вчителя іноземної мови - це забезпечення інтегрально-контамінаційного способу реалізації положень діяльнісного та компетентнісного підходів як домінувально-екстраполяційних та іррадіації положень єдності ієрархічно-підпорядкованих методологічних підходів (в межах здійснюваного дослідження), а саме: комунікативного, системного, синергетичного, аксіологічного, акмеологічного, культурологічного, суб'єктного та особистісно-зорієнтованого у їх комплікативно-контамінаційній взаємодії задля створення сучасного діє-орієнтованого освітнього середовища професійної підготовки вчителя іноземної мови.

Ця умова визначається як загально-всеохоплювальна, котра сприймається як умова вищого ієрархічного рівня, що передбачає конкретизацію через створення комплексу організаційно-дидактичних субумов, котрі своєю чергою конкретизуються як нескінченна низка елементно-часткових умов та забезпечують активацію фрункції визначення домінувального вектора послідовного розгортання цілеспрямованих дидактичних впливів реалізації діяльнісного підходу в професійній підготовці вчителя іноземної мови.

Комплекс організаційно-дидактичних субумов утворюють:

Перша організаційно-дидактична субумова: забезпечення системно-комплексного активування дидактичного потенціалу дисциплін блоку фрахової підготовки як впливу, спрямованого на активацію мотиваційно-самоактуалізаційного складника профресійної підготовки студента-фрілолога як майбутнього вчителя іноземної мови. 
Друга організаційно-дидактична субумова: усвідомлення студентом важливості фрормування й розвитку власної діяльнісної компетентності як основи формування професійної компетентності.

третя організачійно-дидактична субумова: визначення й інтенсифікація діяльнісного спрямування інноваційних освітніх технологій на основі врахування досвіду класичних діє-орієнтованих фрорм організації, методів, прийомів і засобів навчання та їхньої інтеграції 3 інтерактивними методами навчання із застосуванням сучасних IT-технологій.

Четверта організаційно-дидактична субумова: активація дидактичних механізмів цілеспрямованого системно-константного фрормування мовної, мовленнєвої та соціокультурної компетентностей як субкомпетентностей у структурі професійної компетентності вчителя іноземної мови на основі створення відповідного дидактикометодичного забезпечення.

П'ята організаційно-дидактична субумова: розроблення діагносту вального інструментарію для визначення рівня вияву профресійної компетентності майбутнього вчителя іноземної мови $[12$, c. 235].

Висновки. Реалізація діяльнісного підходу в процесі підготовки вчителів іноземних мов на засадах урахування ціннісно-вартісних положень інших методологічних підходів - компетентнісного, комунікативного, системного, синергетичного, аксіологічного, акмеологічного, культурологічного, суб'єктного, особистісно-зорієнтованого - забезпечує дидактично-зумовлену результативність впливу на формування профресійної компетентності майбутніх учителів іноземних мов на ґрунті статистично значущого підвищення ефрективності орормування їхніх суб'єктних якостей як результату активації процесів самоактуалізації та самодіяльності в інфрормаційно-освітньому середовищі сучасного педагогічного закладу вищої освіти.

Результати проведеного експерименту показали позитивні зміни у професійній підготовці майбутніх учителів іноземної мови. Високий рівень підготовки студентів експериментальних груп зріс на $38,2 \%$; середній - на 32,0\%, низький - зменшився на 70\% порівняно 3 результатами констатувального експерименту. Отримані результати засвідчують позитивне значення розробленої моделі фрункційно-структурної дидактичної системи та створення таксономії організаційно дидактичних умов реалізації діяльнісного підходу у процесі підготовки вчителя іноземної мови.

Перспективи подальших наукових пошуків вбачаються у створенні нових концепцій реалізації діяльнісного підходу в навчанні.

\section{БІБЛІОГРАФІЧНИЙ СПИСОК:}

1. Атанов Г. Деятельностный подход в обучении. Донецк : EAU-прес, 2001. С. 160

2. Зимняя И. Ключевые компетенции - новая парадигма результатов современного образования. Высшее образование сегодня. 2003.№ 5. С. 24-26.

3. Леонтьев А. Проблема деятельности в советской психологии. Вопросы психологии. 1986. № 4. C. $109-120$.

4. Малихін О. Особистість студента як суб'єкт самостійної навчальної діяльності в умовах вищого педагогічного навчального закладу. Фаї Педагогіка вищої та середньої школи : [зб. наук. пр.] / Під. ред. проф. В. Буряка. Кривий Ріг : КДПУ,2005. Вип. 11. C. 29-44.

5. Малихін О. Методологічні основи визначення дидактичних умов у дослідженнях 3 теорії навчання: монограсрія. Стратегії інтеріоризації змісту професійної підготовки майбутніх фрілологів: теорія і практика : монографрія (частина перша) / за ред. проф. О. Малихіна. Київ : ЦП «Компринт», 2018. С. 46-72.

6. Реан А. Психология и педагогика. СанктПетербург : Питер, 2000. С. 175.

7. Рубинштейн С. Принцип творческой самодеятельности. Вопросы психологии. 1986. № 4. С. 101-107.

8. Сусь Б., Шут М. Діяльнісний підхід як есрективний спосіб забезпечення дієвості знань. Збірник наукових праць. Педагогічні науки. Бердянськ, 2007. № 4. C. 5-8.

9. Шмир М. Дидактичні основи реалізації діяльнісного підходу в процесі підготовки вчителя іноземної мови : дис. ... д. пед. н. 13.00.09 - теорія навчання. Тернопіль, 2020. С. 47.

10. Щукина Г. Роль деятельности в учебном процессе: [кн. для учителя]. Москва : Просвещение. 1986. C. $15-16$. 